\title{
PRELIMINARY ANALYSIS OF THE PSYCHOMETRIC PROPERTIES OF THE PORTUGUESE VERSION OF THE TEST OF PERFORMANCE STRATEGIES (TOPSp) IN ATHLETES WITH DISABILITIES Tânia Lima Bastos ${ }^{*}$, Rui Corredeira ${ }^{* *}$, Michel Probst ${ }^{* * * *}$, António Manuel Fonseca*
}

\author{
*CIFI2D, Faculty of Sport, University of Porto, Portugal \\ ** CIAFEL, Faculty of Sport, University of Porto, Portugal \\ **** Faculty of Kinesiology and Rehabilitation Sciences, Catholic University of Leuven, Belgium
}

The importance of psychological preparation in the success of athletes is well accepted. However, it still remains a lack of valid and reliable instruments to assess the athletes' psychological skills. The goal of this study was to assess the psychometric properties of a preliminary Portuguese version of the Test of Performance Strategies (TOPSp) in athletes with disabilities. Seventy athletes (age $M=33.3$ yrs; $S D=12.2$ yrs) completed the TOPSp. The questionnaire was translated following the methodological suggestion of Vallerand (1989). The internal consistency of the subscales of the TOPSp was acceptable $(\alpha=.60-.81)$, with the exception of automaticity $(\alpha=.12)$ and activation $(\alpha=.44)$ in practice setting. The paired sample $t$ test between test and retest $(n=12)$ showed no significant differences except to self-talk (competition) $(\mathrm{t}[11]=-2.45, \mathrm{p} \leq 0.05)$. Strong positive correlations between competition subscales $(r=.70-.93)$ and most of the practice subscales $(r=.74-.91)$ were found except to automaticity $(r=.12)$ and activation $(r=.52)$. Regardless of the problems found for the automaticity and activation practice subscales, the results showed acceptable internal consistency and temporal stability of the TOPSp, recommending its use to assess the psychological skills of Portuguese athletes with disabilities.

Key-Words: psychological skills; TOPS; cross-cultural adaptation.

\section{INTRODUCTION}

Nowadays, the importance of psychological preparation in the success of athletes is wellknown. Psychological preparation can be defined as a group of cognitive, emotional and behavioural strategies used by athletes or teams to achieve the optimal psychological state that will influence the ideal performance state for either competition or practice (Gould, Flett, \& Bean, 2009). The physical and technical aspects of performance are influenced by psychological skills that can overshadow or highlight the expected results of any athlete (Weinberg \& Gould, 2011). The control of an athlete's thoughts, emotions and behaviour during performance can be improved with the training of psychological skills (Leffingwell, DurandBush, Wurzberger, \& Cada, 2005) according to the needs and specific characteristics of the athlete.
Concentration and stress management are some examples of the most studied psychological skills that are vital for successful performance in sports. Athletes usually indicate concentration, or the ability to focus on a specific task while ignoring distractions, as an important determinant in sports (Moran, 2009). Stress has a profound impact on an athlete's sport experience and results in an imbalance when athletes compare the demands of competition with their abilities to meet those demands in a successful way (Burton \& Raedeke, 2008). The ability to manage stress will determine a positive or negative competitive experience.

Therefore, psychological skills have a significant influence on athlete's performance achievements and personal development 
(Bonnar, 1997; Burton \& Raedeke, 2008; Gould et al., 2009).

Techniques, such as goal setting, relaxation, imagery and self-talk are often described in literature as important tools in the training of psychological skills. In goal setting, athletes try to achieve a group of behavioural targets previously defined (Brewer, 2009). Goals help to focus attention and enhance an athlete's selfconfidence and motivation (Burton \& Raedeke, 2008). Relaxation techniques require the ability to voluntarily decrease the amount of tension in muscles, calm the mind by keeping it productively occupied, and decrease autonomic responses (e.g., heart rate, blood pressure) (Brewer, 2009). On one hand, it is very important to teach athletes how to relax and cope with stressful situations, while on the other hand, the opposite process - the activation - is crucial. To prepare for optimal performance requires the activation of the body and the mind, achieving higher levels of energy (Burton \& Raedake, 2008). Imagery is a powerful tool to help the athletes in the acquisition of new technical or psychological skills and consists in the creation of mental images associated to multiple senses and emotions (Brewer, 2009). Additionally, psychological benefits such as motivation, confidence and focus are related to the application of this technique (Hale, Seiser, Macguire, \& Weinrich, 2005). Self-talk is typically described as the internal dialogue that athletes develop within themselves. The use of positive self-talk is very important in creating positive thoughts, feelings and behaviour in athletes, and, consequently, in improving the sport outcomes (Brewer, 2009).

Likewise, different studies in sports for athletes with disabilities (e.g., visual impairment, cerebral palsy, physical disability, intellectual disabilities) revealed that psychological preparation represents an important tool in the assistance and the performance of the athletes (Gregg, Hrycaiko, Mactavish, \& Martin, 2004; Hanrahan, Grove, \& Lockwood, 1990; Page \& Wayda, 2001).

Different authors (Castagno, 2001; Hanrahan, 2007; Herbalis, Hatzigeorgiadis, \& Theodorakis, 2008; Martin, 1999a) agree that athletes with disabilities, just like any others, can benefit from the use of psychological techniques to improve their sport performance.

Thus, the training of psychological skills in athletes with disabilities is viable and the challenge is to define the content of the preparation and the adaptation for each athlete individually (Page \& Wayda, 2001). However, researchers have also indicated obstacles that can be detrimental to the studies in the field of sport psychology applied to disability sports, such as the small size of the available samples (Herbalis et al., 2008; Martin, 1999b, 2008; Stamou, Theodorakis, Kokaridas, Perkos, \& Kessanopoulou, 2007), the examination of only one sport or type of disability (Robbins \& Dummer, 2001) and the lack of control of specific variables (e.g., level of competition, level of experience in the sport) (Stamou et al., 2007).

Adequate assessment of psychological skills can be very important to evaluate the level and the use of these skills, to identify athletes' weaknesses and strengths, to monitor improvements and outcomes in psychological training and consequently, to give proper feedback to athletes and coaches. Nevertheless, the lack of appropriate, valid and reliable instruments for measuring the different psychological skills of athletes with disabilities remains a problem (Goudas, Kontou, \& Theodarakis, 2006; Martin, Eklund, \& Mushett, 1997; Skordilis, Sherrill, Villa, Koutsouki, \& Stravrou, 2002).

The choice of single or multi-skills questionnaires also plays an important role. Leffingwell et al. (2005) suggested using a single instrument to assess multiple-skills. A single instrument reduces the assessment time of athletes, although it may also reduce the depth of understanding of certain skills. Likewise, Durand-Bush, Salmela, and Green-Demers (2001) suggested that research and sport psychology consulting with athletes and coaches needed more broad-based instruments to measure a range of psychological skills.

Within this context, the Test of Performance Strategies (TOPS; Thomas, Smith, \& Hardy, 1999) is a multi-skill instrument, applied to athletes with and without disabilities, and examines the level of the use of psychological 
skills in competition and practice settings (Frey, Laguna, \& Ravizza, 2003; Lowther, Lane, \& Lane, 2002; Penna, Burden, \& Richards, 2004; Schliermann \& Danders, 2010; Taylor, Gould, \& Rolo, 2008).

Therefore, this test was preferred above the Psychological Skills Inventory for Sport (Mahoney, Gabriel, \& Perkins, 1987), or the Athletic Coping Skills Inventory-28 (Smith, Schutz, Smoll, \& Ptacek, 1995) that only evaluated the psychological skills in a competitive setting.

The assessment of psychological skills in a practice setting by the TOPS represented an innovation in the research of an athlete's psychological skills. It is known that athletes invest the majority of their time in training, rather than competition. So, if a high psychological performance is expected during competition, this fact cannot be neglected in training routines. Research shows that elite coaches and athletes focus on the best ways to achieve mental readiness in training sessions and not only in competition routines (Gould et al., 2009). Psychological skills must be taught and the athlete must be trained in the use of these skills; systematic practice is required to obtain results. This idea is also supported by Frey et al. (2003), who found a positive relation between the use of psychological skills in practice and the perceived success of the athletes at practice and in a competitive setting.

The range of psychological skills and techniques that TOPS covers at the same time makes its application particular useful when researchers intend to explore populations where information about the level of use of psychological skills is scant. This is the specific case of athletes with disabilities. A comprehensive status of knowledge about psychological skills and techniques, in both competition and training setting, seems to be achieved. Therefore, due to the additional and diversified information that TOPS brings to the research in the field of psychological skills, it's used with all the athletes, regardless their condition, appears to be considered an advantage.

However, in spite of the fact that the TOPS has been used in different studies, there still is a lack of psychometric properties when applied to athletes with disabilities. Indeed, except for the study by Goudas et al. (2006), research in this field seems to be almost non-existent. Goudas et al. (2006) reported good internal consistency, temporal stability and structural validity of the Greek version of the TOPS when used with athletes with physical disabilities. Since the previous mentioned study was the only one found with similar research purpose, it will be used as a reference scheme.

Therefore, the goals of this study were: i) to do the cross-cultural adaptation of the TOPS to use with Portuguese athletes with disabilities, and ii) to assess its psychometric properties.

\section{METHOD \\ Participants}

Seventy males and three female athletes were selected. Due to the significant gender imbalance only male participants (age $M=33.3$ yrs; $S D=12.2$ yrs) were considered. Seventy athletes with physical disability (87\%) and with visual impairment $(13 \%)$ and playing different sports $(73 \%$ wheelchair basketball; $13 \%$ goalball; $10 \%$ swimming; $3 \%$ track and field; $1 \%$ triathlon) participated in the study. Most of the participants $(69 \%)$ had an acquired disability. The sports participation ranged from 1 to 40 years. All athletes played sport at a competitive level (e.g., national and international) and participated in the Portuguese national championships. $40 \%$ of the participants had international experience.

The sampling strategy involved three steps. Firstly, the participants involved in the early stages of the study, namely the evaluation of the questionnaire by the target population and content validity (e.g., pre-test group and individual interview), were convenient selected. Athletes that trained in the same city of residence of the main researcher and showed availability to contribute for the content validity procedures were considered. Next, for the following phases of research we considered a "geographical location" criterion. Clubs located in the same geographical district of the first author residence were selected. Finally, in order to enlarge the sample size and the recruitment of participants from different regions of the 
country, a purposive sampling method was applied, i.e. based on the different "Season Schedules" of the different sports. In this manner, the first author attended several sport competitions and contacted the participating clubs who were enrolled in competition at the time of data collection. This was decided because not all of the sports competitive seasons started at the same time period.

\section{Instrument}

The Test of Performance Strategies (TOPS; Thomas et al., 1999) was conceived to measure the psychological skills and strategies applied in practice and competition settings by athletes.

The TOPS is a 64-item questionnaire composed of eight self-regulation and performance enhancement subscales (goal setting, emotional control, automaticity, relaxation, activation, self-talk, imagery and attentional control). All subscales are common in practice as well as in competitive settings, with the exception of attentional control: this subscale is replaced by negative thinking in competition. Each subscale (skill) is composed of four items and each item scored on a fivepoint Likert scale $(1=$ Never, $3=$ Sometimes and 5=Always).

Structural validity of the questionnaire was established using exploratory factor analysis and adequate values of internal consistency were found (practice subscales $\alpha=.66-.81$; competition subscales $\alpha=.74-.80)$. Test-retest reliability procedures were not reported. The instrument created by Thomas et al. (1999) was found to discriminate among a wide variety of sports as well as different levels of competition (e.g., internationally; nationally; regional, junior and recreational standards).

Additionally, demographic (e.g., gender, date of birth, type and etiology of disability, nationality and qualifications) and sport features (e.g., type of sport, years of competition, hours of practice per week, number of national and international competition per year and prior sport psychology support) were questioned.

\section{Procedures}

Data collection occurred during the 2009/2010 sport season. The first author informed managers, head coaches of the teams and athletes about the study goals.

Practical information on how to complete the questionnaire was given. There were no right or wrong answers, and athletes were encouraged to answer according to their typical behaviour in practice and competition settings. In athletes with visual impairment, an individual interview format was applied.

This research was reviewed and approved by the committee responsible for the ethical issues. Athletes gave their informed consent to participate in the study. Parental consent was requested for those participants under the age of 18. The questionnaire took approximately $15-20$ minutes to be completed.

\section{Data analysis}

The methodological suggestion of Vallerand (1989) was followed for the cross-cultural adaptation of the TOPS for Portuguese language (TOPSp). The author presented a systematic approach for the cross-cultural validation of psychological questionnaires in 7 phases: i) preparation of a preliminary version; ii) evaluation and changes in the preliminary version; iii) evaluation of semantic comprehension of the questions by the target population (pre-test); iv) evaluation of the content validity of the questionnaire; v) evaluation of reliability (test-retest) and internal consistency of the instrument; vi) construct validity determination and vii) establishment of standard values or norms. For the purpose of the present investigation the first five phases were followed.

The statistical procedures were carried out using the Statistical Package for Social Sciences SPSS (17.0), and the data was introduced in SPSS by a mechanism of optical reading TELEform.

Cronbach's alpha was used to establish the internal consistency of the psychological skills' subscales and temporal stability was examined through the Spearman Correlation and paired sample $T$ Test $(\mathrm{p} \leq 0.05)$. A test-retest was administered on 12 athletes (age $M=31.7$ yrs; $S D=8.4$ yrs) with physical disabilities who completed the questionnaire twice within a twoweek interval. Most of the athletes had acquired 
disability ( $n=8)$ and were wheelchair basketball players and track and field athletes.

\section{RESULTS}

Elaboration and evaluation of the preliminary version

The first phase of the transcultural validation of the TOPS was the elaboration of a preliminary version of the original questionnaire into the Portuguese language. Three Portuguese sport psychology specialists, with an excellent knowledge of the English language, translated the original version of the TOPS combining two techniques: i) translation-back-translation and, ii) jury panel. Due to the lexical diversity of the Portuguese language a panel of two specialists supported and supervised the first procedure conducted by a single individual. The panel checked both translated versions (Portuguese and English) and then, the three specialists together discussed and defined the preliminary version of the questionnaire.

In the second phase of this process, different sport psychologists and coaches revised the questionnaire. They evaluated the semantic equivalence of the concepts, contents and word comprehensibility. The 64 original items of the questionnaire were kept and only two items related to automaticity scales (Item 30: "During competition I perform on 'automatic pilot"' and Item 48 "During practice sessions I just seem to be in a flow") were adjusted.

Therefore, it was suggested that more information about those subjects be added to the questionnaire. Following this suggestion, and trying to clarify the meaning of "flow" (Item 48), a brief and practical definition of the concept was added in the introductory header of the questionnaire and in the item itself. Since, this word does not have an equivalent in the Portuguese language, it was decided that would be useful to provide more information to the athletes ("Flow-The physical and psychological state of balance that allows the optimal performance; the athlete is completely focused on a high level of performance, active and completely separated from distractions" (Caruso, 2004)).
A similar procedure was taken on Item 30 in relation to the expression "automatic pilot", which is not frequently used in the Portuguese language. ("Automatic pilot" was replaced by "in an automatic way"). A brief definition of automaticity was added in the header of the questionnaire. ("It is the ability to perform skills or actions in an automatic way without reasoning the movements; it allows one to focus attention on other factors of sport performance and be less influenced by internal or external distractions" (Thomas et al., 1999)).

Evaluation of the questionnaire by the target population (pre-test) and content validity

The goal of a pre-test is to determine if the items that comprise the questionnaire are clear, meaningful and without ambiguities for the target population (Vallerand, 1989).

Regarding the pre-test we followed two procedures. Firstly, a group of 20 athletes with physical disabilities were requested to complete the questionnaire. Attached to the questionnaire was a blank sheet of paper where the athlete could write his/her comments about the questionnaire, including i) unclear comprehension of the items; ii) ambiguous concepts; iii) problematic items and, iv) additional comments. Most of the athletes did not indicate problems with comprehending the items on the questionnaire, but eight raised doubts about the meaning of activation. In order to clarify the activation subscales an explanation of the psychological construct was added to the questionnaire. ("It is the ability to activate the body and the mind, increasing the level of energy, the blood rate, the muscular activity, the motivation and the focus. It is the state that athletes reach when they are ready to perform at their highest level" (Burton \& Raedeke, 2008)).

Secondly, we interviewed a male wheelchair basketball player, aged 20, with a physical disability, and three years of competitive experience in the national wheelchair basketball championship. The aim of the interview was to examine in depth the athlete's comprehension of the questionnaire. Therefore, the athlete was asked to report what he understood and what he would answer in each item of the questionnaire. After the content analyses of the interview we 
concluded that no difficulties or disparities were evident.

Evaluation of reliability and internal consistency of the questionnaire

To analyse the precision of the Portuguese version of the TOPS (TOPSp) to evaluate the psychological constructs in athletes with disabilities, we used the Cronbach alpha.

Table 1 presents the descriptive statistics and the Cronbach's alpha values in practice and competition subscales of our study. Clearly, the automaticity $(\alpha=.12)$ and activation $(\alpha=.44)$ practice subscales revealed problems.

Table 1 -Descriptive statistic of the TOPSp (mean, standard deviation) and Cronbach's alpha values in practice and competition subscales $(n=70)$

\begin{tabular}{lcccccc}
\hline & \multicolumn{3}{c}{ Practice } & \multicolumn{3}{c}{ Competition } \\
\hline & $\mathrm{M}$ & $\mathrm{SD}$ & $\alpha$ & $\mathrm{M}$ & $\mathrm{SD}$ & $\alpha$ \\
\hline Goal Setting & 3.80 & .73 & .71 & 3.92 & .74 & .77 \\
Emotional & 2.85 & .41 & .72 & 3.46 & .77 & .79 \\
$\begin{array}{l}\text { Control } \\
\text { Automaticity }\end{array}$ & 3.09 & .51 & .12 & 2.74 & .81 & .74 \\
Relaxation & 3.11 & .79 & .75 & 3.36 & .76 & .67 \\
Self-Talk & 3.44 & .81 & .80 & 3.37 & .86 & .81 \\
Imagery & 3.22 & .72 & .61 & 3.19 & .72 & .71 \\
Activation & 3.29 & .47 & .44 & 3.78 & .64 & .74 \\
$\begin{array}{l}\text { Attentional } \\
\text { Control }\end{array}$ & 3.80 & .64 & .65 & - & - & - \\
$\begin{array}{l}\text { Negative } \\
\text { Thinking }\end{array}$ & - & - & - & 2.04 & .76 & .67 \\
\hline
\end{tabular}

Another procedure that was carried out in order to measure the reliability of the questionnaire was the temporal stability $(n=12)$.

Table 2 presents the descriptive statistics, paired sample $t$-test and Spearman's correlations values in practice and competition subscales.

In a practice setting, paired sample $t$-test showed no statistically significant differences on item means between coupled test-retests $(p \geq 0.05)$. Spearman rank order correlation coefficients indicated strong positive correlations in most of the practice subscales $(r=$ $.74-0.91 ; p \leq 0.01)$ between the two moments; the exceptions were the subscales of automaticity $(r=.12)$ and activation ( $r=.51)$.

In a competition setting, paired sample $t$-test showed no statistically significant differences on item means between coupled test-retests $(\mathrm{p} \geq 0.05)$ with the exception of self-talk ( $\mathrm{t}[11]=$ $-2,45, p \leq 0.05)$. Spearman rank order correlation coefficients indicated strong and positive $(r=.70$ $-.93 ; \mathrm{p} \leq 0.01)$ correlations.

Table 2 - Test-retest and Spearman's correlation of the TOPSp for a two-week interval $(n=12)$

\begin{tabular}{lccccccc}
\hline \multicolumn{7}{c}{ Test } & \multicolumn{1}{c}{ Re-test } \\
& M & SD & M & SD & $\mathbf{t}$ & $\mathbf{p}$ & $\mathbf{\rho}$ \\
\hline Practice & & & & & & & \\
Subscales & & & & & & & \\
Goal Setting & 3.75 & .60 & 3.96 & .62 & - & .12 & $.74^{* *}$ \\
Emotional & 3.19 & .67 & 3.10 & .42 & .84 & .42 & $.91^{* *}$ \\
Control & & & & & & & \\
Automaticity & 3.04 & .53 & 3.15 & .51 & .50 & .63 & .12 \\
Relaxation & 3.06 & .62 & 2.79 & .57 & 2.11 & .06 & $.75^{* *}$ \\
Self-Talk & 3.41 & .75 & 3.63 & .77 & - & .06 & $.89^{* *}$ \\
Imagery & 3.08 & .81 & 3.23 & .54 & -.88 & .40 & $.79^{* *}$ \\
Activation & 3.75 & .48 & 3.56 & .49 & - & .20 & .52 \\
Attentional & 3.83 & .58 & 3.85 & .56 & -.17 & .87 & $.77^{* *}$ \\
Control & & & & & & & \\
Competition & & & & & & & \\
Subscales & & & & & & & \\
Goal Setting & 3.75 & .61 & 3.88 & .80 & - & .33 & $.83^{* *}$ \\
Emotional & 3.58 & .73 & 3.65 & .62 & -.66 & .52 & $.86^{* *}$ \\
Control & & & & & & & \\
Automaticity & 2.56 & .95 & 2.47 & .95 & .88 & .40 & $.93^{* *}$ \\
Relaxation & 3.65 & .76 & 3.49 & .83 & 1.10 & .30 & $.86^{* *}$ \\
Self-Talk & 3.40 & .64 & 3.65 & .62 & - & $.03^{*}$ & $.73^{* *}$ \\
Imagery & 3.19 & .74 & 3.33 & .46 & -.99 & .35 & $.82^{* *}$ \\
Activation & 3.92 & .50 & 3.77 & .58 & 1.29 & .22 & $.74^{* *}$ \\
Negative & 1.88 & .77 & 1.88 & .74 & .00 & 1.00 & $.70^{*}$ \\
Thinking & & & & & & & \\
\hline & & & & & & &
\end{tabular}

$$
\begin{aligned}
& * * \rho \leq 0.01 \text { level } \\
& * \rho \leq 0.05
\end{aligned}
$$

Table 3 shows the Cronbach's alpha values in different studies using the Test of Performance Strategies Questionnaire in athletes 
with and without disabilities. The data from this table will be used to explore comparability of internal consistency values in the next section of the study.

Table 3 - Cronbach's alpha values in different studies using the TOPS in athletes with and without disabilities.

\begin{tabular}{lcccc}
\hline \multicolumn{5}{c}{ Alpha Coefficients of The Test of Performance Strategies Questionnaire } \\
\hline & TOPSp & $\begin{array}{c}\text { Goudas et al., } \\
(2006)\end{array}$ & $\begin{array}{c}\text { Thomas et al., } \\
(1999)\end{array}$ & $\begin{array}{c}\text { Lane et al., } \\
(2004)\end{array}$ \\
\hline Practice Subscales & & & & \\
Goal-Setting & .71 & .98 & .78 & .79 \\
Emotional Control & .72 & .97 & .72 & .73 \\
Automaticity & .12 & .98 & .67 & .62 \\
Relaxation & .75 & .99 & .78 & .75 \\
Self-Talk & .80 & .99 & .81 & .76 \\
Imagery & .61 & .98 & .72 & .75 \\
Activation & .44 & .94 & .66 & .57 \\
Attentional Control & .65 & .94 & .73 & .68 \\
Competition Subscales & & & & .80 \\
Goal-Setting & .77 & .97 & .78 & .72 \\
Emotional Control & .79 & .96 & .79 & .74 \\
Automaticity & .74 & .98 & .74 & .80 \\
Relaxation & .67 & .98 & .80 & .77 \\
Self-Talk & .81 & .99 & .80 & .82 \\
Imagery & .71 & .89 & .79 & .76 \\
Activation & .74 & .97 & .74 & .96 \\
Negative Thinking & .67 & .98 & & .79 \\
\hline
\end{tabular}

\section{DISCUSSION}

This study aimed to establish a preliminary Portuguese version of the Test of Performance Strategies (TOPS) (Thomas et al., 1999) to use with athletes with disabilities and to assess its psychometric properties.

The 64 items of the TOPS established by Thomas et al. (1999) were translated into the Portuguese language (TOPSp).

Additional information was incorporated in order to clarify the concepts of flow, activation and automaticity (competition and practice). Some concepts were difficult to translate or were not used in the Portuguese language. In the Greek version of the TOPS, the authors kept the 64 original items and made minor changes in some items related to self-talk, activation, negative thinking (competition) and attentional control (practice) (Goudas et al., 2006). Doubts concerning the comprehensibility of the activation construct appear to be common in both studies. The meaning of "activation" can raise doubts to the athletes because it is a process that implies the global energization of the body and mind. The athlete must learn how to speed up the heart rate, respiration and how to increase the blood flow to muscles (Burton \& Raedake, 2008). It is possible that most of the athletes ignore the existence of proper techniques that allow the voluntary control of the physiological parameters to perform at a 
high level. Simultaneously, activation requires the enhancement of brain activity. However, the raising of psychological energy must be conducted in a beneficial way, and it seems that not all the athletes reveal the ability to do it by themselves.

In the present study, internal consistency values ranged between .12 and .80 in practice subscales, and between .67 and .81 in competition subscales. Vallerand (1989) suggested appropriate values of internal consistence ranging between .70 and .85 . However, Loewenthal (2001) indicated that an alpha of .60 is also acceptable for subscales containing four items. On the other hand, high scores of Cronbach's alpha (above .90) demonstrated redundancy of the items and consequently, the repetition of the items in each subscale (Vallerand, 1989).

Globally, the internal consistency values of the TOPSp indicated that the items that comprised each subscale were positively correlated and this preliminary study suggested acceptable reliability of the questionnaire for goal setting, emotional control, relaxation, selftalk, imagery, attentional control and negative thinking subscales. However, it is necessary to clarify the problems that automaticity and activation subscales revealed, specifically in a practice setting. Debois, Quillet, Sylvestre, and Calmels (2004) found similar problems when testing the French version of the TOPS. Although a different methodological procedure (varimax rotation) was used in this study, the automaticity subscale in the practice setting also showed unacceptable Cronbach's alpha values $(\alpha=.41)$. Because not enough items saturated in the activation subscale the authors did not determine the internal consistency for the practice setting. Penna et al. (2004) applied the TOPS to a sample of athletes with and without physical disabilities and found unacceptable alpha coefficients using the original structure of the questionnaire. However, the exact values were not reported in the study. The authors used an amended 10 factor structure, with three items per factor, and removed automaticity and activation subscales as well as attentional control (practice) and negative thinking (competition) subscales.
Automaticity is the ability to perform skills, movements or actions in an automatic way without giving thought or reason to the action. This capacity allows the athletes to focus attention on the more important issue of the performance and leaves them less vulnerable to internal or external distractions. The feeling of performing in an automatic way is typical of the flow state, when athletes achieve the peak performance (Singer, 2002).

Therefore, the ability to perform at a high standard without constantly thinking is related to the development of an expert stage (Thomas et al., 1999). However, the level of experience of the athletes in our sample was very heterogeneous. The number of years of competition ranged from less than 1 to 40 years and the number of hours of practice per week ranged from 2 to 42 hours. As such, this can be one explanation for the problems in the automaticity subscale in a practice setting.

The importance of automaticity can vary according to the type of sport (e.g., open/close skills, predictable/unpredictable sport variables) that is being analysed. Singer (2002) studied automaticity in self-paced sports and events. In self-paced situations, athletes have stable and predictable environment conditions, and there is sufficient time to analyse circumstances for preparing to perform. In our case, athletes from different sports were studied (e.g., goalball, wheelchair basketball, triathlon, swimming and track and field) and this fact could also influenced the data.

In a similar study, Goudas et al. (2006) tested the Greek version of the TOPS in athletes with physical disabilities. The authors did not find any problems in the automaticity and activation practice subscales.

Moreover, all the scores in practice and competition were higher than ours in all subscales. One of the factors that can influence this result is the characteristics of the sample. In our study, the 70 athletes that completed the TOPSp had different types of disabilities and played different sports whereas, Goudas et al. (2006) examined 50 participants, all of whom were track and field athletes with physical disability. The athletes had participated in sports over six-year period, while our sample exhibited 
a large range of sport experiences ranging from less than 1 year to 40 years. However, neither study examined the influence of these specific variables (e.g., type of disability, type of sport, sport experience) on the psychological skills of the athlete. The heterogeneity of our sample can be seen as a limitation to our findings. In the original TOPS study, Thomas et al. (1999) reported moderated reliability in automaticity subscale in a practice setting. The authors explained that athletes could have been confusing genuine automaticity with a laissezfaire attitude and misunderstood the concept of the skill.

In a study examining the factorial validity of the TOPS with adolescents, Lane, Harwood, Terry, and Karageorghis (2004) indicated the importance of using proper language in the items of the questionnaire in order to allow for a correct understanding of the concepts by the athletes. Meaningful responses require the understanding of the concept of an automatic navigation system what can be inappropriate for certain groups (e.g., adolescents). Goudas et al. (2006) also indicated that athletes were unable to comprehend the significance of automaticity in a practice setting. Since the goal of practice is to learn new abilities or improve skills, athletes considered automaticity impossible. Other specific aspects that may be relevant are if the athletes know or understand how they can train automaticity, which strategies can be used to improve this skill, or on the contrary, if they just do not think it is possible to train automaticity.

Possibly, the activation subscale had the same problem in a practice setting. Doubts can be raised about the way in which the athletes understood the concept of activation and if they did, how they conceived the training of this skill. We can, therefore, question if the athletes believe if it is possible to train in the area of activation and if they know how to do it. Likewise, Thomas et al. (1999) and Lane et al. (2004) found moderated to poor reliability in activation subscale in a practice setting.

In early phases of this research, changes were made in the original questionnaire in order to help the Portuguese athletes to better understand automaticity and activation concepts. However, further research using the
TOPSp should investigate the possibility to change, to remove or to add new items to these specific subscales.

The internal consistency of the competition subscales revealed acceptable values in our study and this is in agreement with Goudas et al. (2006), Thomas et al. (1999) and Lane et al. (2004).

In a practice setting, paired sample $t$-test showed no statistically significant differences on item means between coupled test-retest. A similar situation was found in competition subscales with the exception of self-talk.

The greater or lesser appeal to self-talk, over time, may be related to the work of a specific technique, which during the competition may or may not require the use of this psychological method. Another possible explanation for the differences in self-talk is the importance that athletes assign to a specific competition. Positive self-talk is an important technique to increase the concentration level and maintain focus during competition (Burton \& Raedeke, 2008). In most important competitions athletes tend to engage in abundant self-talk in order to achieve the ideal psychological state in which to perform. Hardy, Hall, and Hardy (2004) studied a group of 291 athletes in a variety of sports (individual/team sports) and in a wide range of skill levels (from recreational to international standards). The goal of their research was to determine how athletes use self-talk and if it varied throughout the sporting calendar. Seventy-five percent of the sample confirmed that the level of use of self-talk increased as the season progressed. However, in our study, we did not control the competitive schedule of the athletes during the two-week interval for retesting. Therefore, we were unable to control the different demands of competition overtime. This limitation can be overcome with a qualitative indepth research to understand the use of self-talk by athletes in a competitive setting. It could also be a contribution to overcome the lack of knowledge about the use of this specific technique by athletes with disabilities as suggested in the study of Stamou et al. (2007) which analysed the effect of self-talk on the penalty execution in goalball.

The Spearman correlation between test and 
retest indicated high-cross correlations in both settings with the exception of automaticity and activation practice subscales that revealed serious problems. Goudas et al. (2006) pointed out that neither setting showed statistically significant differences on item means between test-retest, and there was a very high crosscorrelation between the two measurements.

These results support our findings that athletes did not correctly understand automaticity and activation. Nevertheless, results can also suggest that during training, athletes do not apply or use these skills on a systematic base. This may be related to a different level of development of the Portuguese disability sports. Although, all the athletes participated in sport at a competitive level, the demands of each sport are quite variable. In certain sports (e.g., goalball), the opportunities to train and to compete are considerably reduced which may influence the psychological preparation and, consequently, the successful use of psychological skills. As a result, the use of psychological skills can be intermittent or sporadic. This background combined with the scant delivery of psychological services in sports can influence the ability of the athletes to improve their psychological skills and can be seen as a limitation to the research in this field. Therefore, future studies should try to control specific variables (e.g., competition level, experience in sport, number of national and international competitions and hours of practice per week).

Although, from a statistical point of view, it could be interesting to enlarge the sample size, this preliminary study revealed acceptable internal consistency and temporal stability on most of the subscales of the Portuguese version of the TOPS (TOPSp). The data suggested that the TOPSp can be used with athletes with disabilities and can represent an important tool in monitoring the training process of the athlete and assessing their psychological skills in competition.

\section{PERSPECTIVE}

The existence of valid and reliable instruments to assess the psychological skills of athletes with disabilities is an important issue for research and practice in the field of sport psychology. Consequently, sport psychologists, coaches, athletes and practioners in general can make substantial improvements to the intervention in psychological skills if proper instruments are available. The implementation of systematic psychological skills training programs is greatly dependent on instruments that assess the evolution and improvements of the athlete's skills.

In the specific case of Portuguese disability sports, this situation is even more crucial due to the nonexistence of valid and reliable instruments to support the psychological preparation of the athletes in practice and competition settings. Further research is necessary to establish cross-cultural psychometric properties and to go deeper in this preliminary analysis of the Portuguese version of the TOPS for athletes with disabilities. This would be an important step to accomplish the final validation of the instrument.

\section{Acknowledgements}

We would like to acknowledge Martin Mansell and Judith Oakley collaboration in the English editing of the paper. This research was funded by the Portuguese Foundation for Science and Technology (FCT).

\section{REFERENCES}

Bonnar, K. (1997). Psychological/Mental Skills.Disability Sport Web Site Retrieved 15 March of 2009, from http://edweb6.educ.msu.edu/kin866/Resea arch/resbonnar1.htm.

Brewer, B. W. (2009). Introduction. In B. W. Brewer (Ed.), Handbook of Sports Medicine and Science: Sport Psychology (pp. 1-6): Wiley-Blackwell Publishing. doi:10.1002/9781444303650.ch1

Burton, D. \& Raedeke, T. D. (2008). Sport Psychology for Coaches. Champaign, IL: Human Kinetics.

Caruso, A. (2004). Sport Psychology Basics. Spring City: Reedswain Publishing.

Castagno, K. S. (2001). Special Olympics Unified Sports: Changes in Male Athletes During a Basketball Season. Adapted 
Physical Activity Quarterly, 18(2), 193206.

Debois, N., Quillet, J., Sylvestre, A., \& Calmels, C. (2004). Contribution à la validation en langue française d'un outil de mesure des stratégies mentales: les "test des stratégies de performance". [Contribution to the validation of a French tool assessing mental strategies: the "Performance Strategy Test"] Paper presented at the Annual Meeting of the French Society of Sport Psychology, University Joseph Fourier: Grenoble.

Durand-Bush, N., Salmela, J. H., \& GreenDemers, I. (2001). The Ottawa Mental Skills Assessment Tool (OMSAT-3*). The Sport Psychologist, 15, 1-19.

Frey, M., Laguna, P. L., \& Ravizza, K. (2003). Collegiate athletes' mental skill use and perceptions of success: an exploration of the practice and competition settings. Journal of Applied Sport Psychology, 15(2), 115-128. doi:10.1080/10413200305392

Goudas, M., Kontou, M. G., \& Theodorakis, Y. (2006). Validity and reliability of the Greek version of the Test of Performance Strategies (TOPS) for athletes with disabilities. Japanese Journal of Adapted Sport Science, 4 (1), 29-36.

Gould, D., Flett, M. R., \& Bean, E. (2009). Mental preparation for training and competition. In B. W. Brewer (ed.), Handbook of Sports Medicine and Science: Sport Psychology (pp. 53-63): Wiley-Blackwell Publishing. doi:10.1002/9781444303650.ch6

Gregg, M. J., Hrycaiko, D., Mactavish, J. B., \& Martin, G. L. (2004). A Mental Skills Package for Special Olympics Athletes: A Preliminary Study. Adapted Physical Activity Quarterly, 21(1), 4-18.

Hale, B. D., Seiser, L., McGuire, E.J., \& Weinrich, E. (2005). Mental Imagery. In J. Taylor \& G. Wilson (Eds.), Applying Sport Psychology: Four Perspectives (pp. 117 - 135). Champaign, IL: Human Kinetics.

Hanrahan, S. J. (2007). Athletes with Disabilities. In G. Tenenbaum \& R. C. Eklund (eds.), Handbook of Sport Psychology ( $3^{\text {rd }}$ ed., pp. 845-858).

New Jersey: John Wiley and Sons, Inc. doi: 10.1002/97811182700-11.ch38

Hanrahan, S. J., Grove, J. R., \& Lockwood, R. J. (1990). Psychological Skills Training for the Blind Athlete: A Pilot Program. Adapted Physical Activity Quarterly, 7(2), 143-155.

Harbalis, T., Hatzigeorgiadis, A., \& Theodorakis, Y. (2008). Self-talk in Wheelchair Basketball: the effects of an intervention program on dribbling and passing performance. International Journal of Special Education, 23(3), 6269.

Hardy, J., Hall, C. R., \& Hardy, L. (2004). A note on athletes' use of self-talk. Journal of Applied Sport Psychology, 16, 251-257. doi: 10.1080/10413200490498357

Lane, A., Harwood, C., Terry, P., \& Karageorghis, C. (2004). Confirmatory factor analysis of the Test of Performance Strategies (TOPS) among adolescent athletes. Journal of Sport Sciences, 22(9), 803-812. doi: 10.1080/02640410410001716689

Leffingwell, T. R., Durand-Bush, N., Wurzberger, D., \& Cada, P. (2005). Psychological Assessment. In J. Taylor \& G. Wilson (Eds.), Applying Sport Psychology: Four Perspectives (pp. 85100). Champaign, IL: Human Kinetics.

Loewenthal, K. M. (2001). An introduction to psychological tests and scales $\left(2^{\text {nd }}\right.$ ed.). London: Psychology Press.

Lowther, J., Lane, A., \& Lane, H. (2002). Self-efficacy and psychological skills during The Amputee Soccer World Cup. Athletic Insight - The Online Journal of Sport Psychology, 4(2), 23-34.

Mahoney, M. J., Gabriel, T. J., \& Perkins, T. S. (1987). Psychological skills and exceptional athletic performance. The Sport Psychologist, 1 (3), 181-199.

Martin, J. J. (1999a). A personal development model of sport psychology for athletes with disabilities. Journal of Applied Sport Psychology, 11(2),181-193. doi:10.1080/10413209908404199 
Martin, J. J. (1999b). Predictors of Social Physique Anxiety in Adolescent Swimmers With Physical Disabilities. Adapted Physical Activity Quarterly, 16(1), 75-85.

Martin, J. J. (2008). Multidimensional SelfEfficacy and Affect in Wheelchair Basketball Players. Adapted Physical Activity Quarterly, 25(4), 275-288.

Martin, J. J., Eklund, R. C., \& AdamsMusheet, C. (1997). Factor structure of the athletic identity measurement scale with athletes with disabilities. Adapted Physical Activity Quarterly, 14, 74-82.

Moran, A. P. (2009). Attention, concentration and thought management. In B. W. Brewer (Ed.), Handbook of Sports Medicine and Science: Sport Psychology (pp. 18-29): Wiley-Blackwell Publishing. doi:10.1002/9781444303650.ch3

Page, S. J., \& Wayda, V. K. (2001). Modifying sport psychology services for athletes with cerebral palsy: suggestions for professional practice. Palaestra, 17(1), 10-14.

Penna, P. G., Burden, S. A., \& Richard, G. E. (2004). Are elite athletes with disabilities mentally tougher than able-bodied competitors? Paper presented at the $3^{\text {rd }}$ International Biennial SELF Research Conference, Berlin. Retrieved 31 October of 2011, from

http://www.self.ox.ac.uk/Conferences/200 4_Penna_Burden_Richards.pdf.

Robbins, J. E., \& Dummer, G. M. (2001). Using Sport Psychology with Athletes with a Disability: A Call for Coach Education. Disability Sport Web Site Retrieved 17 March of 2009, from http://edweb6.educ.msu.edu/kin866/Resea rch/resrobbins 1.htm.

Schliermann, R., \& Danders, D. (2010). Psychological skills of elite athletes with a disability. Conference Proceedings of the European Congress of Adapted Physical Activity, 117. European Federation of Adapted Physical Activity (EUCAPA) and Finnish Society of Sport Sciences. Jyväskylä, Finland.

Singer, R. N. (2002). Preperformance state, routines, and automaticity: What does it take to realize expertise in self-paced events? Journal of Sport and Exercise Psychology, 24, 359-375.

Skordilis, E. K., Sherrill, C., Villa, A., Koutsouki, D., \& Stavrou, K. A. (2002). Use of the Sport Orientation Questionnaire with wheelchair athletes: examination of evidence for validity. Perceptual and Motor Skills, 95(1), 197207. doi:10.2466/pms.2002.95.1.197

Smith, R. E., Schutz, R.W., Smoll, F. L. \& Ptacek, J. T. (1995). Development and validation of a multidimensional measure of sport-specific psychological skills: The Athletic Coping Skills Inventory-28. Journal of Sport and Exercise Psychology, 17, 379-398.

Stamou, E., Theodorakis, Y., Kokaridas, D., Perkos, S., \& Kessanopoulou, M. (2007). The effect of self-talk on the penalty execution in goalball. British Journal of Visual Impairment, 25(3), 233-247.

Taylor, M.K., Gould, D., \& Rolo, C. (2008). Performance strategies of US Olympians in practice and competition. High Ability Studies, 19, 19-36.doi: 10.1080/026404109

Thomas, R. P., Murphy, S. M., \& Hardy, L. (1999). Test of performance strategies: development and preliminary validation of a comprehensive measure of athletes' psychological skills. Journal of Sports Sciences, 17, 697-711.

Vallerand, R. J. (1989). Vers une méthodologie de validation transculturelle de questionnaires psychologiques: Implications pour la recherche en langue française [Towards a methodology for cross-cultural validation of psychological questionnaires: Implications for research in French lamguage]. Psychologie Canadienne [Canadian Psychology], 30(4), 662-680.

Weinberg, R. S., \& Gould, D. (2011). Foundations of sport and exercise psychology $\left(5^{\text {th }}\right.$ ed.). Champaign, IL: Human Kinetics.

Corresponding author's e-mail address: tbastos@fade.up. 
(Abstract)

\section{VORLÄUFIGE ANALYSE DER PSYCHOMETRISCHEN EIGENSCHAFTEN DER PORTUGIESISCHEN VERSION DES 'TEST OF PERFORMANCE STRATEGIES' (TOPS) FÜR SPORTLER(INNE)N MIT BEHINDERUNG}

Die Bedeutung der psychologischen Vorbereitung für den Erfolg von Sportler(inne)n wird allgemein anerkannt. Dennoch fehlt es noch immer an validen und reliablen Instrumenten zur Erfassung von psychologischen Fähigkeiten der Sportler/innen. Das Ziel dieser Studie war es, die psychometrischen Eigenschaften einer vorläufigen portugiesischen Version des 'Test of Performance Strategies' (TOPSp) für Sportler/innen mit Behinderung zu überprüfen. Siebzig Athlet(inn)en (M=33,3 Jahre; SD=12,2 Jahre) beantworteten den TOPSp. Der Fragebogen wurde gemäß den methodologischen Vorgaben von Vallerand (1989) übersetzt. Die interne Konsistenz der Subskalen des TOPSp waren annehmbar $(\alpha=0.60-.81)$, mit Ausnahme von Automatik $(\alpha=0.12)$ und Aktivierung im Setting Praxis $(\alpha=0.44)$. Der gepaarte t-Test zwischen Test und Re-Test $(\mathrm{n}=12)$ zeigte keine signifikanten Unterschiede außer bezüglich der Selbstgespräche (im Wettkampf) $(\mathrm{t}[11]=-2.45, \mathrm{p} \leq 0.05)$. Es konnten stark positive Korrelationen zwischen Wettkampf Subskalen $(\alpha=0.70$ - .93) und den meisten der Praxis-Subskalen $(\alpha=0.74-.91)$ mit Ausnahme Automatik $(\alpha=0.12)$ und Aktivierung $(\alpha=0.52)$ gefunden werden. Unter Außerachtlassung der Probleme, die bei Automatik und Aktivierung festgestellt wurden, zeigten die Ergebnisse akzeptable interne Konsistenz und zeitliche Stabilität de TOPSp und er kann daher seine Nutzung zur Überprüfung der psychologischen Fertigkeiten von portugiesischen Sportler(inne)n mit Behinderung empfohlen werden.

Schlüsselwörte: Psychologische Fähigkeiten; TOPS; interkulturelle Adaptierung

(Résumé)

\section{ANALYSE PRÉLIMINAIRE DES PROPRIÉTÉS PSYCHOMÉTRIQUES DE LA VERSION PORTUGAISE DES TESTS DES STRATEGIES DE PERFORMANCES CHEZ LES ATHLÈTES HANDICAPÉS.}

L'importance de la préparation psychologique dans la performance des athlètes est bien admise. Cependant, il reste encore un manque d'instruments valides et fiables pour évaluer les compétences psychologiques des athlètes. Le but de cette étude était d'évaluer les propriétés psychométriques de la version préliminaire portugaise du « Test of Performance Strategies » (TOPSp) chez les athlètes porteurs de handicap. Soixante-dix athlètes (Moyenne d'âge $=33,3 \pm 12,2$ ans) ont complété le TOPSp. Le questionnaire a été traduit en suivant la méthodologie de Vallerand (1989). La cohérence interne des sous-échelles du TOPSp semblaient acceptables $(\alpha=0,60$ à 0,81$)$, à l'exception de l'automaticité $(\alpha=0,12)$ et l'activation en milieu de pratique $(\alpha=0,44)$. La comparaison test - retest $(\mathrm{n}=12)$ n'a pas montré de différence significative à l'exception du « selftalk » (compétition) ( $\mathrm{t}[11]=-2,45, \mathrm{p} \leq 0,05)$. De fortes corrélations positives entre les sous-échelles de la compétition $(\alpha=$ de 0,70 à 0,93$)$ et la plupart des sous-échelles $(\alpha=$ pratique de 0,74 à 0,91$)$ 
ont été trouvés à l'exception d'automaticité $(\alpha=0,12)$ et l'activation $(\alpha=0,52)$. Quels que soient les problèmes rencontrés pour les sous-échelles de l'automatisation et de l'activation en milieu de pratique, les résultats ont montré une cohérence interne et une stabilité temporelle acceptable du TOPSp, recommandant ainsi son utilisation pour évaluer les compétences psychologiques des athlètes portugais handicapés.

Mots Clés : compétences psychologiques, TOPSp, adaptations interculturelles

(Аннотацця)

\section{АНАЛИЗ ПРЕДСТАРТОВОЙ ПОДГОТОВКИ ПСИХОМЕТРИЧЕСКИХ СВОЙСТВ СПОРТСМЕНОВ С ОГРАНИЧЕННЫМИ ВОЗМОЖНОСТЯМИ НА ОСНОВЕ ТЕСТА ПОРТУГАЛЬСКОЙ ВЕРСИИ}

Общепринятым является тот факт, что актуальность психологической подготовки спортсмена для достижения успеха достаточно высока. Но всё ещё отсутствуют действенные и надежные методы её оценки. Целью данного исследования была оценка предстартового состояния психометрических свойств посредством португальской версии теста (далее просто ТЕСТ) для спортсменов с ограниченными возможностями. Семьдесят спортсменов (средний возраст $\mathrm{M}=33,3$ лет; $\mathrm{SD}=12,2$ лет) приняли участие в тестировании. Вопросник был переведен в соответствии с методологическими предложениями Валлеранда (1989). Внутренняя непротиворечивость (совокупности критериев) шкал в ТЕСТе были приемлемыми ( $\alpha=0,60$ - 0,81), за исключением критерия автоматизма $(\alpha=0,12)$ и критерия активации установки на практике $(\alpha=0,44)$. Повторное тестирование (перепроверка) (n= 12) не показало никаких существенных различий, кроме разговора с самим собой (конкурс) $(\mathrm{T}[11]=-2.45$, при $\mathrm{p} \leq 0,05)$. Была определена сильная положительная корреляция между шкалой конкуренция ( $\alpha=0,70$ - 0,93), и большинством критериев практика $(\alpha=0,74-0,91)$, кроме автоматизма $(\alpha=0,12)$ и активации $(\alpha=0,52)$. Несмотря на проблемы, связанные с противоречиями критерия автоматизма $(\alpha=0,12)$ и критерием активации установки на практике $(\alpha=0,44)$, результаты показали приемлемую внутреннюю согласованность и временную стабильность португальской версии ТЕСТа, что дает основание для рекомендации его использования для оценки психологических навыков спортсменов с ограниченными возможностями.

Ключевые слова: психологические навыки; ТЕСТ; межкультурная адаптащия

(Resumen)

\section{ANÁLISIS PRELIMINAR DE LOS PROPIEDADES PSICOMÉTRICAS DE LA VERSIÓN EN PORTUGUÉS DE LA PRUEBA DE LAS ESTRATEGIAS DE RENDIMIENTO EN ATLETAS CON DISCAPACIDAD (TOPS)}


Es bien aceptada la importancia de la preparación psicológica en el éxito de los atletas. Sin embargo, sigue siendo ostensible la falta de instrumentos válidos y fiables para evaluar las habilidades psicológicas de los atletas. El objetivo de éste estudio fue evaluar las propiedades psicométricas de una versión preliminar portuguesa de la prueba de Estrategias de Rendimiento en los Atletas con Discapacidad (TOPSp). Setenta atletas $(M=33,3$ años; $D E=12,2$ años) completaron el TOPSp. El cuestionario fue traducido a raíz de la sugerencia metodológica de Vallerand (1989). La consistencia interna de las subescalas de la TOPSp eran aceptables $(\alpha=0,60$ a $0,81)$, con la excepción de la dimensiones automatismo $(\alpha=0,12)$ y activación en la fijación de la práctica $(\alpha=0,44)$. La muestra de la prueba t pareada $(n=12)$ no mostró diferencias significativas, excepto para la competencia de auto-hablado ( $\mathrm{t}[11]=-2,45, \mathrm{p} \leq 0,05)$. Se encontraron grandes correlaciones positivas entre las subescalas de competencia $(\alpha=0,70$ a 0,93$)$ y la mayoría de las subescalas de práctica $(\alpha=0,74$ a 0,91$)$, con excepción de automaticidad $(\alpha=0,12)$ y la activación $(\alpha=0,52)$. Independientemente de los problemas encontrados para el automatismo y las subescalas de activación de la práctica, los resultados mostraron una aceptable consistencia interna y estabilidad temporal para el TOPSp, lo que hace recomendable su uso para evaluar las habilidades psicológicas de los deportistas portugueses con discapacidad.

Palabras clave: habilidades psicológicas; TOPS, adaptación transcultura

(Resumo)

\section{ANÁLISE PRELIMINAR DAS PROPRIEDADES PSICOMÉTRICAS DA VERSÃO PORTUGUESA DO TEST OF PERFORMANCE STRATEGIES (TOPS) EM ATLETAS COM DEFICIENNCIA}

A importância da preparação psicológica no sucesso obtido pelos atletas é algo bem aceite. No entanto, existe ainda uma lacuna de instrumentos válidos e fidedignos para a avaliação de competências psicológicas em atletas. O objectivo do presente estudo foi avaliar as propriedades psicométricas de uma versão preliminar em língua Portuguesa do Test of Performance Strategies (TOPSp) em atletas com deficiência. Setenta atletas ( $\mathrm{M}=33,3$ anos; $\mathrm{DP}=12,2$ anos) completaram o preenchimento do TOPSp. O questionário foi traduzido seguindo as sugestões metodológicas apresentadas por Vallerand (1989). A consistência interna das subescalas do TOPSp foi aceitável ( $\alpha$ $=0,60-, 81)$, com a excepção da automaticidade $(\alpha=0,12)$ e activação em contextos de prática $(\alpha=$ $0,44)$. $\mathrm{O}$ valor do teste $\mathrm{T}$ de pares entre o teste e o re-teste $(\mathrm{n}=12)$ não apresentou diferenças significativas excepto para o autodiscurso (competição) $(\mathrm{t}[11]=-2,45, \mathrm{p} \leq 0,05)$. Foram encontradas correlações fortes e positivas entre as subescalas da competição $(\alpha=0,70-, 93)$ e a maioria das subescalas da prática $(\alpha=0,74-, 91)$ excepto para a automaticidade $(\alpha=0,12)$ e a activação $(\alpha=$ 0,52). Apesar dos problemas encontrados nas escalas de automaticidade e de activação para a prática do TOPSp, os resultados obtidos apresentam um nível aceitável de consistência interna e de psicológicas de atletas Portugueses com deficiência.

Palavras-Chave: competências psicológicas; TOPS; adaptação transcultural 